\title{
Pain-induced depression in the elderly: Validation of psychometric properties of the Brazilian version of the "Geriatric Emotional Assessment of Pain" - GEAP-b
}

\author{
Carla Bezerra lopes Almeida ${ }^{1 *}$, Ricardo Humberto Félix ${ }^{1}$, Maysa Seabra Cendoroglo², Fania Cristina Santos ${ }^{2}$ \\ ${ }^{1}$ Affiliated Physician of the Osteoarticular Disease and Pain Service, Division of Geriatrics and Gerontology (DIGG), Universidade Federal de São Paulo (Unifesp), São Paulo, SP, Brazil \\ 2PhD Professor, DIGG, Unifesp, São Paulo, SP, Brazil
}

Study conducted at the Division of Geriatrics and Gerontology (DIGG), Universidade Federal de São Paulo

(Unifesp), São Paulo, SP, Brazil

Article received: $11 / 25 / 2016$ Accepted for publication: $2 / 5 / 2017$

*Correspondence: Address: Rua Francisco de Castro, 105 São Paulo, SP - Brazil Postal code: 04024-002 dra.carlabezerra@gmail.com

http://dx.doi.org/10.1590/1806-9282.63.09.741 Funding: private

\section{SUMMARY}

Objective: In order to introduce an instrument within our midst that allows a comprehensive clinical evaluation of pain-induced depression in the elderly, we proposed the translation, cross-cultural adaptation into Brazilian Portuguese, and study of the psychometric properties of the "Geriatric Psychosocial Assessment of Pain-induced Depression" (GEAP) scale. This instrument was especially developed for the screening of depression associated with chronic pain in the elderly.

Method: We performed translation and cross-cultural adaptation of the GEAP scale, whose psychometric properties were analyzed in a sample of 48 elderly individuals. Sociodemographic data and information related to chronic pain were ascertained, as well as those related to depression. The GEAP-b scale was applied at three different times on the same day by two different interviewers (I1 and I2), and after 15 days by one of those interviewers (I3).

Results: The GEAP-b proved to be an easy-to-apply instrument with a high internal consistency value, according to the Cronbach's alpha coefficient (0.835). The reproducibility of the instrument was optimal, achieving intraclass correlations of 98.5 and $92 \%$ for interobserver and intraobserver, respectively. There was "considerable" agreement (between 0.419 and 1.0) for each GEAP-b item, except for item 19, according to the kappa statistic. As for the validity of the GEAP-b criterion, positive and statistically significant correlations were obtained for pain, according to GPM-p $(\mathrm{r}=49.5 \%, \mathrm{p}<0.001)$, and depression, according to GDS ( $\mathrm{r}=59 \%, \mathrm{p}<0.001)$, both values being considered regular (between 40-60\%).

Conclusion: The GEAP-b scale has proven to be reliable and valid in the screening of pain-related depression in the elderly.

Keywords: elderly, chronic pain, depression, cross-cultural comparison, validation studies.

\section{INTRODUCTION}

About $50 \%$ of the community's elderly and $80 \%$ of those living in long-term care facilities experience chronic pain. ${ }^{1}$ These individuals are more likely to suffer from depression, and therefore are more at risk of increased intensity, frequency and duration of pain. ${ }^{2}$ This direct relation was demonstrated in a study in which patients with multiple pain symptoms were three to five times more likely to have depression, while those with a "single" symptom of pain were twice as likely to have this mood disorder. ${ }^{2}$

Elderly individuals with depression and chronic pain, compared to those with depressed mood only, have more suicidal ideation, sleep disorders and personality disorders, in addition to longer hospitalizations and greater use of the health system. ${ }^{3}$ A vicious cycle takes place that interferes with the adequate treatment of both comorbidities. ${ }^{4}$ Thus, adequate diagnosis of pain-induced depression cannot be established unless depression and pain are examined concomitantly rather than through separate assessment tools. $^{5}$

Studies with individuals with chronic pain and depression have shown that less than half of those with depression were correctly diagnosed, with consequent treatment impairment. ${ }^{2}$ The "Geriatric Emotional Assess- 
ment of Pain" - GEAP scale was developed to identify the level of depression induced by pain, which in turn is defined as depression triggered by chronic pain mainly due to beliefs about pain that are formed around the socialized meaning of convictions about pain by older adults at two levels: catastrophization and perceived deficiency. ${ }^{5}$ We attempted to test a biopsychosocial multidimensional assessment basis and to identify the level of pain-induced depression in elderly people with chronic pain, thus improving pain management in those individuals.

The GEAP scale is a tool to evaluate pain-related depression in the elderly, ${ }^{5}$ and its use by health professionals in Brazil would enable a more consistent assessment of pain-induced depression in the aging population. This resource would allow early action, and less functional, social, psychological and health damages in the elderly with pain.

\section{Method}

This was a methodological, descriptive and analytical study, approved by the Ethics Committee of the Federal University of São Paulo in 2014 (CEP No. 528,139).

For translation and cross-cultural adaptation of the GEAP scale, we followed the methodology by Guillemin et al. ${ }^{6}$ First, the text of the questionnaire in English was translated into Portuguese by two independent Brazilian translators, qualified and aware of the translation objectives. The translations obtained were compared to one another, originating a version that was back translated into English. This version was compared with the original in English by two native English-speaking translators with knowledge of the Portuguese language, unaware of the proposed objectives.

For cross-cultural adaptation, some equivalences were obtained: 1) Semantic equivalence, based on the comparison of grammatical and vocabulary aspects, refers to the fact that many words in a language may not have equivalents in other languages; 2 ) Idiomatic equivalence, which involves a vast research of dictionaries, refers to the difficulty of translating certain idiomatic expressions as the meaning of words is sometimes neither fixed nor stable; 3) Transcultural or experimental equivalence, that is, the cross-cultural context of the original expressions must have "content validity" in Brazilian Portuguese and meaning for the Brazilian population, always having in mind that the original version of the instrument will be used in a different country; 4) Conceptual equivalence, refers to the idea that some words can be semantically equivalent without presenting "concept equivalence." In this last stage, we assembled a committee of five special- ists from different areas who were experienced in the elderly: a geriatrician, a physiotherapist, a psychologist, an occupational therapist and a nurse. Thus, the final version of the instrument was obtained: the GEAP-b (Chart 1).

The instrument comprised 25 yes or no questions, structured into three different social levels of pain: eight questions about beliefs about pain, eight about perceived deficiency, and nine questions about pain interference in cognition. The total GEAP score is obtained by summing

CHART 1 GEAP-b - Translated version, adapted transculturally to Brazil.

GEAP-b Yes No

1. Did the pain leave you physically disabled?

2. Because of the pain, did you isolate yourself

from others?

3. Is the pain treatment too expensive for you?

4. Has the pain changed your sleeping habits?

5. Has the pain affected your appetite?

6. Does pain keep you from doing the activities you

enjoy doing?

7. Does pain prevent you from relaxing?

8. Do you believe that your pain has no solution?

9. Does being physically active only cause you

more pain?

10. Does the pain make you feel like you cannot go on living?

11. Does pain prevent you from planning the future?

12. Does pain make you feel worthless?

13. Is pain a punishment for bad things you have done

to others in the past?

14. Does pain lead to bad things in your life?

15. Will the pain prevent you from ever being

happy again?

16. Does pain make you not control how you feel?

17. Is it true that you will never be able to do anything

for yourself because of the pain?

18. Do you constantly complain of pain?

19. Does telling the doctor about your pain only make things worse?

20. Do you deal with the pain just by lying in bed?

21. Do you stop doing everything when you feel pain?

22. Is it true that you will never understand what

causes your pain?

23. Does your family tell you that with pain it is difficult to live with you?

24 . Have your parents ever talked about physical pain?

25 . Do you talk to your friends about your pain? 
the number of affirmative answers. The classification is given as follows: 0-5 points, little or no pain-induced depression; 5-9 points, moderate pain-induced depression; and 10 or more points, severe pain-induced depression. ${ }^{1}$

For the study of the psychometric properties of the newly created instrument, elderly individuals aged 80 years or older, participants of the "Longevos Project" of the Division of Geriatrics and Gerontology (DIGG) of the Federal University of São Paulo (Unifesp) were selected between May 2014 and January 2015. ${ }^{7}$ This project refers to a longitudinal epidemiological study that includes long-lived individuals of both sexes, residents of the community, who are able to walk without assistance (but can use walking aids). Those with cognitive impairment diagnosed after clinical evaluation and/or cognitive tests; severe acute or chronic decompensated acute disease; under current treatment with dialysis, chemo or radiotherapy; hospitalized in the past 3 months; with sequelae from stroke or myocardial vascular accident; with impaired visual or auditory deficits; and those who were totally dependent on others for basic daily activities were excluded.

Thus, our population was composed of a convenience sample, obtained from a non-probabilistic sampling method dependent on the collection of data from members of the population that were conveniently available to participate in the study. Individuals with chronic pain lasting six months or longer, as defined by the International Association for the Study of Pain (IASP), ${ }^{8}$ and with pain intensity greater than or equal to 3 , according to a visual numeric scale (VNS) of pain, ${ }^{9-12}$ were included. All participants signed a free and informed consent form.

Sociodemographic characteristics were obtained, as well as the medications used for pain and depression, and data on chronic pain, which was measured unidimensionally based on VNS, and multidimensionally according to the Geriatric Pain Measure (GPM-p). ${ }^{13}$ Depressive symptoms were tracked according to the Geriatric Depression Scale (GDS), short version..$^{14,15}$

The GEAP-b was applied by two independent interviewers (I1 and I2) on the same day and after 15 days without any intervention during the period, followed by a third evaluation by one of the interviewers (I3). This was done in order to obtain reliability and validity, as recommended by methodological studies on measurement instruments. ${ }^{16}$ Reliability was analyzed based on internal consistency (correlations between items) and reproducibility (test-retest and inter-observer analysis).

During the validation process some methods are proposed, including "face validity" (if the instrument measures what is supposed to be measured) and "content validity" (if the object of measurement is representative), both obtained in the transcultural adaptation process. ${ }^{11}$ "Construct validity" (evaluates previously operationalized constructs using empirical data) was also proposed, but not obtained due to the absence of an instrument considered gold standard for measurement of depression in patients with chronic pain. Then, we obtained the "criterion validity", which assessed the degree of efficacy in the prediction of pain-induced depression ${ }^{18}$ based on the correlation between the GEAP-p score and the assessments of depression and pain using GDS and GPM, respectively.

For statistical analysis, we used SPSS version 17 and Microsoft Excel 2010. For the characterization of the distribution and the frequency of qualitative variables, we adopted the Equivalence Test for Two Proportions, for the Internal Consistency we used Cronbach's Alpha Coefficient, and for reproducibility Student's t-test, Intraclass Correlation Coefficient (ICC) and Kappa Concordance Index. Also, the Pearson correlation was used for validation. The significance level was set at 5\%.

\section{Results}

The sample consisted of 48 elderly individuals with mean age of $87.5 \pm 4.1$ years (81-99 years). The participants were predominantly female $(79.2 \%)$, white $(79.2 \%)$, widows/ widowers (58.3\%) and presented low formal education (60.4\% studied for 1 to 4 years).

Most used pain medications regularly (64.6\%), either classic analgesics $(56.3 \%)$ or drugs with adjuvant action on pain (31.3\%). Antidepressants were used by $45.8 \%$ of the sample.

Chronic pain had a mean duration of 9.26 years and intensity was mainly moderate (35.4\%) or severe (54.2\%), according to VNS. In the multidimensional analysis (GPM-p), it was considered mainly moderate (68.8\%). Regarding the nature of pain, there was a predominance of nociceptive (79.2\%), mainly in the joints (81.3\%).

Depression was identified in $39.6 \%$ of the elderly according to the GDS scale. The prevalence among participants of moderate pain-induced depression was $33.3 \%$ and severe in $20.8 \% .45 .8 \%$ of the sample had mild or no depression.

In the evaluation of the psychometric properties of the GEAP-p, starting with the reliability according to its internal consistency, high values of Cronbach's alpha were obtained: 0.835 for I1, 0.834 for I2 and 0.795 for I3. For reproducibility, three analyzes were performed. According to the paired Student's t-test, no significant interobserver (I1 and I2) and intraobserver (I1 and I3) differences were observed, with a coefficient of variation greater than 50\% indicating heterogeneity (Table 1). The 
ICC showed excellent results, with $98.5 \%$ interobserver correlation (I1 and I2) and 92\% intraobserver correlation (I1 and I3). According to the analysis of agreement between the interviewers for each item of the instrument in question, using Kappa statistics, statistically significant concordances were obtained between I1 and I 2 and I1 and I3, which were considered good, with a single exception for item 19 (I1 and I3) (Table 2).

TABLE 1 GEAP reproducibility, according to paired Student's t-test.

\begin{tabular}{lllll} 
GEAP-b & $\mathbf{I 1}$ & $\mathbf{I 2}$ & $\mathbf{I 3}$ & $\mathbf{p}$-value \\
\hline Total & 48 & 48 & 42 & \\
\hline Mean & 6.67 & 6.58 & 6.86 & \\
\hline Median & 6 & 5.5 & 6 & \\
\hline Standard deviation & 4.62 & 4.60 & 4.28 & \\
\hline Coefficient of variation (\%) & 69 & 70 & 62 & \\
\hline Min & 0 & 0 & 0 & \\
\hline Max & 21 & 21 & 18 & \\
\hline Confidence interval & 1.31 & 1.30 & 1.29 & \\
\hline Correlation I1/I2 & & & & 0.605 \\
\hline Correlation I1/I3 & & & & 0.360 \\
\hline
\end{tabular}

TABLE 2 Intraobserver and interobserver agreement, according to the Kappa index.

\begin{tabular}{lllll} 
& $\mathbf{I 1 / 1 2}$ & \multicolumn{3}{l}{$\mathbf{I 1 / 1 3}$} \\
\cline { 2 - 5 } & Kappa & p-value & Kappa & p-value \\
\hline Question 1 & 0.750 & $<0.001$ & 0.571 & $<0.001$ \\
\hline Question 2 & 0.727 & $<0.001$ & 0.494 & 0.001 \\
\hline Question 3 & 0.762 & $<0.001$ & 0.690 & $<0.001$ \\
\hline Question 4 & 0.865 & $<0.001$ & 0.642 & $<0.001$ \\
\hline Question 5 & 0.735 & $<0.001$ & 0.690 & $<0.001$ \\
\hline Question 6 & 0.775 & $<0.001$ & 0.586 & $<0.001$ \\
\hline Question 7 & 0.845 & $<0.001$ & 0.669 & $<0.001$ \\
\hline Question 8 & 0.787 & $<0.001$ & 0.561 & $<0.001$ \\
\hline Question 9 & 0.645 & $<0.001$ & 0.518 & 0.001 \\
\hline Question 10 & 0.833 & $<0.001$ & 0.876 & $<0.001$ \\
\hline Question 11 & 0.829 & $<0.001$ & 0.651 & $<0.001$ \\
\hline Question 12 & 0.899 & $<0.001$ & 0.666 & $<0.001$ \\
\hline Question 13 & 1.000 & $<0.001$ & 0.482 & $<0.001$ \\
\hline Question 14 & 0.862 & $<0.001$ & 0.618 & $<0.001$ \\
\hline Question 15 & 0.850 & $<0.001$ & 0.639 & $<0.001$ \\
\hline Question 16 & 1.000 & $<0.001$ & 0.659 & $<0.001$ \\
\hline Question 17 & 0.550 & $<0.001$ & 0.419 & 0.006 \\
\hline Question 18 & 0.858 & $<0.001$ & 0.654 & $<0.001$ \\
\hline Question 19 & 0.657 & $<0.001$ & -0.050 & 0.746 \\
\hline & & & & $($ Continues) \\
\hline
\end{tabular}

TABLE 2 (Cont.) Intraobserver and interobserver agreement, according to the Kappa index.

\begin{tabular}{lllll} 
& $\mathbf{I 1 / \text { I2 }}$ & \multicolumn{3}{l}{$\mathbf{I 1 3}$} \\
\cline { 2 - 5 } & Kappa & $\mathbf{p}$-value & Kappa & P-value \\
\hline Question 20 & 0.644 & $<0.001$ & 0.641 & $<0.001$ \\
\hline Question 21 & 0.813 & $<0.001$ & 0.556 & $<0.001$ \\
\hline Question 22 & 0.695 & $<0.001$ & 0.738 & $<0.001$ \\
\hline Question 23 & 0.897 & $<0.001$ & 0.540 & $<0.001$ \\
\hline Question 24 & 0.492 & $<0.001$ & 0.774 & $<0.001$ \\
\hline Question 25 & 0.775 & $<0.001$ & 0.738 & $<0.001$ \\
\hline I1: Interviewer 1; 12: Interviewer 2; I3: Interviewer 3. & &
\end{tabular}

11: Interviewer 1; 12: Interviewer 2; 13: Interviewer 3.

As for validation, according to the Pearson statistic, the GEAP-b showed a positive and significant correlation with depression (GDS) and pain (GPM), respectively: $r=59 \%$ and $\mathrm{r}=49.5 \%$, both considered regular (between $40-60 \%$ ).

\section{Discussion}

We obtained an instrument that the elderly were able to understand easily, GEAP-b, which is simple to apply and requires little time (about 5 minutes). We have included a unique long-lived sample, which is the portion of the elderly population that grows the most throughout the world, ${ }^{19}$ mostly comprising females $(79.2 \%)$ and similar to that found in the scientific literature considering the population over 80 years old (feminization of aging). ${ }^{20}$

Regarding pain, we observed the presence of impacting pain, with a majority of participants referring moderate to severe intensity, a rather prolonged duration ( 9.26 years), and high impact on the life of the elderly according to the GPM-p (social engagement, pain while walking, pain during vigorous activities, and more). This finding is similar to another Brazilian study conducted in the city of Londrina, which found a higher prevalence of moderate to severe pain (60.4\%) among the elderly in the community. ${ }^{21}$

The diagnosis of possible depression, according to GDS, was found in almost $40 \%$ of patients, reaching $54 \%$ in pain-induced depression. This mood disorder is about two to three times higher among individuals with chronic pain, and there is a vicious cycle of worsening pain in patients with depression and vice versa, leading to losses directly proportional to the intensity of the illnesses. ${ }^{22-25}$ In population studies, the prevalence of depression in individuals with chronic pain is $18 \%$, and in primary services the incidence reaches 37 to $56 \% .{ }^{22}$ Onder et al. found a $19.5 \%$ prevalence of depression in a European population of long-lived patients with chronic pain. ${ }^{26}$

Analyzing the measurement properties of GEAP-b, firstly referring to its internal consistency, we verified that 
it was considered good or excellent. That is, good or excellent reliability was observed for the vast majority of items in this instrument.

For reproducibility, and according to the Kappa agreement that evaluates the extent to which the variability represents the mean, very good results (I1-I2 and I1-I3) were obtained, except for agreement in item 19, which did not compromise the reproducibility. Thus, GEAP-b can be considered an instrument of good reliability.

In the validation process, face and content validities were considered adequate, and especially, the criterion validity. For the latter, we observed statistically significant, regular and positive correlations of GEAP-b with "multidomain" depression and pain. In the case of positive correlations, the higher the GEAP-b score, the higher the level of pain-induced depression observed.

The existence of a gold standard evaluation test would certainly help and enrich the GEAP validation process. A larger sample and comparison studies with other instruments for screening and assessing the severity of depression (such as the Hamilton Depression Scale - HAM-D and the Montgomery-Asberg Depression Rating Scale - MADRS) are valuable in enhancing the validity of this instrument.

The GEAP was applied by interviewers, and a selfassessment by most of the study participants is not possible due to their difficulty in reading the questions in the questionnaire, which was probably due to the low educational level (60.4\% studied from 1 to 4 years) of the sample, and can be considered another limitation of our study.

Self-application of the GEAP by the patient is feasible and can be performed in the waiting room of the physicians' offices, and also by other health professionals. This measure is relevant, since there is an increase in the interest of researchers in studying aging and its consequences. Chronic pain in the elderly, as well as chronic pain associated with depression, would thus be important in clinical practice, since these conditions are associated with compromising outcomes. Further research is needed, and the cut-off points require additional validation in the Brazilian medical setting.

\section{Conclusion}

We obtained an instrument of easy applicability and good understanding by the elderly: the GEAP-b. It was appropriately translated and adapted transculturally to Brazil, and after the analysis of its measurement properties, proved to be reliable and valid for the identification of pain-induced depression in the elderly.

\section{ACKNOWLedGMENTS}

We thank geriatrician Fernanda Gazoni, physiotherapist Paulo Mateus Costa Affonso, psychologist Maria Angela Mello Barreto Guimarães and occupational therapist Mariella Bessa, specialists who composed our expert committee for the process of transcultural adaptation of the questionnaire into Brazilian Portuguese.

\section{Conflict of interest}

The authors declare no conflict of interest.

\section{Resumo}

Depressão dor-induzida em idosos: validação das propriedades psicométricas da versão brasileira do "Geriatric Emotional Assessment of Pain" - GEAP-b

Objetivo: A fim de se introduzir no nosso meio um instrumento que permitisse uma avaliação clínica abrangente da depressão dor-induzida em idosos, propôs-se a tradução, adaptação transcultural para o Brasil e estudo das propriedades psicométricas do "Geriatric Psychosocial Assessment of Pain-induced Depression” (GEAP). Esse instrumento foi desenvolvido especialmente para rastreio da depressão associada à dor em idosos.

Método: Foram realizadas tradução e adaptação transcultural do GEAP, cujas propriedades psicométricas foram analisadas em uma amostra de 48 idosos. Foram apurados dados sociodemográficos e relacionados a dor crônica, além de depressão. O GEAP-b foi aplicado em três momentos distintos, em um mesmo dia por dois entrevistadores diferentes (E1 e E2), e após 15 dias por um daqueles entrevistadores (E3).

Resultados: O instrumento GEAP-b mostrou-se ser de fácil aplicação e alto valor de consistência interna, de acordo com o coeficiente alfa de Cronbach $(0,835)$. Teve reprodutibilidade ótima, segundo as correlações intraclasses: valores de 98,5 e 92\%, interobservador e intraobservador, respectivamente. As concordâncias para cada item do GEAP-b foram "consideráveis" (entre 0,419 e 1,0 ), excetuando-se a concordância para o item 19 , segundo a estatística kappa. Para a validade de critério do GEAP-b, correlações positivas e estatisticamente significativas foram obtidas para a dor, segundo o GPM-p $(\mathrm{r}=49,5 \% ; \mathrm{p}<0,001)$, e para a depressão, segundo o GDS $(r=59 \% ; p<0,001)$, com ambos os valores considerados regulares (entre 40 e $60 \%$ ).

Conclusão: O GEAP-b demonstrou ser confiável e válido no rastreio da depressão associada à dor em idosos. 
Palavras-chave: idoso, dor crônica, depressão, comparação transcultural, estudos de validação.

\section{References}

1. Wilson JE. A Geriatric psychosocial assessment of pain-induced depression. Washington (DC): Walden University; 2011.

2. Bair MJ, Robinson RL, Katon W, Kroenke K. Depression and pain comorbidity: a literature review. Arch Intern Med. 2003; 163(20):2433-45.

3. Meeks TW, Dunn LB, Kim DS, Golshan S, Sewell DD, Atkinson JH, et al. Chronic pain and depression among geriatric psychiatry inpatients. Int $\mathrm{J}$ Geriatr Psychiatry. 2008; 23(6):637-42.

4. Mavandadi S, Ten Have TR, Katz IR, Durai UNB, Krahn DD, Llorente MD, et al. Effect of depression treatment on depressive symptoms in older adulthood: the moderating role of pain. J Am Geriatr Soc. 2007; 55(2):202-11.

5. LLpez-L:202 A, Montorio I, Izal M, Velasco L. The role of psychological variables in explaining depression in older people with chronic pain. Aging Ment Health. 2008; 12(6):735-45.

6. Guillemin F, Bombardier C, Beaton D. Cross-cultural adaptation of healthrelated quality of life measures: literature review and proposed guidelines. J Clin Epidemiol. 1993; 46(12):1417-32.

7. Santos FC, Moraes NS, Pastore A, Cendoroglo MS. Chronic pain in longlived elderly: prevalence, characteristics, measurements and correlation with serum vitamin D level. Rev Dor. 2015; 16(3):171-5.

8. Merskey NB. Classification of chronic pain: descriptions of chronic pain syndromes and definitions of pain terms prepared by the International Association for the Study of Pain. 2. ed. Seattle: IASP Press; 1994

9. Gagliese L, Weizblit N, Ellis W, Chan VW. The measurement of postoperative pain: a comparison of intensity scales in younger and older surgical patients. Pain. 2005; 117(3):412-20.

10. Herr KA, Spratt K, Mobily PR, Richardson G. Pain intensity assessment in older adults: use of experimental pain to compare psychometric properties and usability of selected pain scales with younger adults. Clin J Pain. 2005; 20(4):207-19.

11. Jones KR, Fink R, Hutt E, Vojir C, Pepper GA, Scott-Cawiezell J, et al. Measuring pain intensity in nursing home residents. J Pain Symptom Manage. 2005; 30(6):519-27.

12. Peters ML, Patijn J, Lam I. Pain assessment in younger and older pain patients: psychometric properties and patient preference of five commonly used measures of pain intensity. Pain Med. 2007; 8(7):601-10.
13. Ferrell BA, Stein WM, Beck JC. The Geriatric Pain Measure: validity, reliability and factor analysis. J Am Geriatr Soc. 2000; 48(12):1669-73.

14. Almeida OP, Almeida SA. Short versions of the geriatric depression scale: a study of their validity for the diagnosis of a major depressive episode according to ICD-10 and DSM-IV. Int J Geriatr Psychiatry. 1999; 14(10):858-65.

15. Almeida OP, Almeida SA. Confiabilidade da versão brasileira da escala de depressão em geriatria (GDS) versão reduzida. Arq Neuropsiquiatr. 1999; 57(2B):421-6.

16. Carmines G, Zeller RA. Reliability and validity assessment. EUA: Sage Publications; 1979. [Series: Quantitative Applications in the Social Sciences, 17].

17. Lorenzet IC, Santos FC, Souza PM, Gambarro RC, Coelho S, Cendoroglo MS. Avaliação da dor em idosos com demência: tradução e adaptação transcultural do instrumento PACSLAC para a língua portuguesa. Rev Bras Med. 2011; 68(4):129-33.

18. Pasquali L. Validade dos testes psicológicos: será possível reencontrar o caminho? Psic Teor Pesq. 2007; 23(N. esp.):99-107.

19. Kirkwood T. A systematic look at an old problem: as life expectancy increases, a systems-biology approach is needed to ensure that we have a healthy old age. Nature. 2008; 451(7):644-7.

20. Carvalho JAM, Wong LR. A transinsin old problem: as life expectancy increases, a systems-biology approach is needed to ensure that we have a healthy old

21. Dellaroza MSG, Furuya RK, Cabrera MAS, Matsuo T, Trelha C, Yamada KN, et al. Caracterização da dor crônica e métodos analgésicos utilizados por idosos da comunidade. Rev Assoc Med Bras. 2008; 54(1):36-41.

22. Gambassi G. Pain and depression: the egg and the chicken story revisited. Arch Gerontol Geriatr. 2009; (49 Suppl 1):103-12.

23. Von Korff M, Dworkin SF, Le Resche L, Kruger A. An epidemiologic comparison of pain complaints. Pain. 1988; 32(2):173-83.

24. Lamb SE, Guralnik JM, Buchner DM, Ferrucci LM, Hochberg MC, Simonsick $\mathrm{EM}$, et al. Factors that modify the association between knee pain and mobility limitation in older women: the Women's Health and Aging Study. Ann Rheum Dis. 2000; 59(5):331-7.

25. Landi F, Onder G, Cesari M, Russo A, Barillaro C, Bernabei R; SILVERNETHC Study Group. Pain and its relation to depressive symptoms in frail older people living in the community: an observational study. J Pain Symptom Manage. 2005; 29(3):255-62.

26. Onder G, Landi F, Gambassi G, Liperoti R, Soldato M, Catananti C, et al. Association between pain and depression among older adults in Europe: results from the Aged in Home Care (AdHOC) project: a cross-sectional study. J Clin Psychiatry. 2005; 66(8):982-8. 